\title{
A world-wide view of venereal disease
}

\author{
R. R. WILLCOX \\ St. Mary's Hospital, London, W.2, and King Edward VII Hospital, Windsor
}

The extent of the problem SYPHILIS AND GONORRHOEA

During the past decade in most countries there has been a noticeable increase in the venereal diseases following the sharp decline after the Second World War which accompanied the more settled conditions of peace and the introduction of quick easy treatments.

\section{Received for publication August 2, 1971}

Paper presented at the International Venereal Disease Symposium, St. Louis, Missouri, U.S.A., organized by the American Social Health Association and Pfizer Laboratories, April 15-16, 1971
Although the reported incidence of primary and secondary syphilis has risen markedly in some countries, in others the infection has been more or less contained (Fig. 1), as for example in New Zealand (Platts, 1969). Many cases, however, are not reported, and in one country at least (e.g. the U.S.A.) infectious syphilis has been described as 'epidemic', second as a communicable disease only to streptococcal sore throat, and far exceeding tuberculosis and poliomyelitis in prevalence (Webster, 1970a). On the other hand, there has been a decline in the numbers of cases of late symptomatic syphilis in countries where

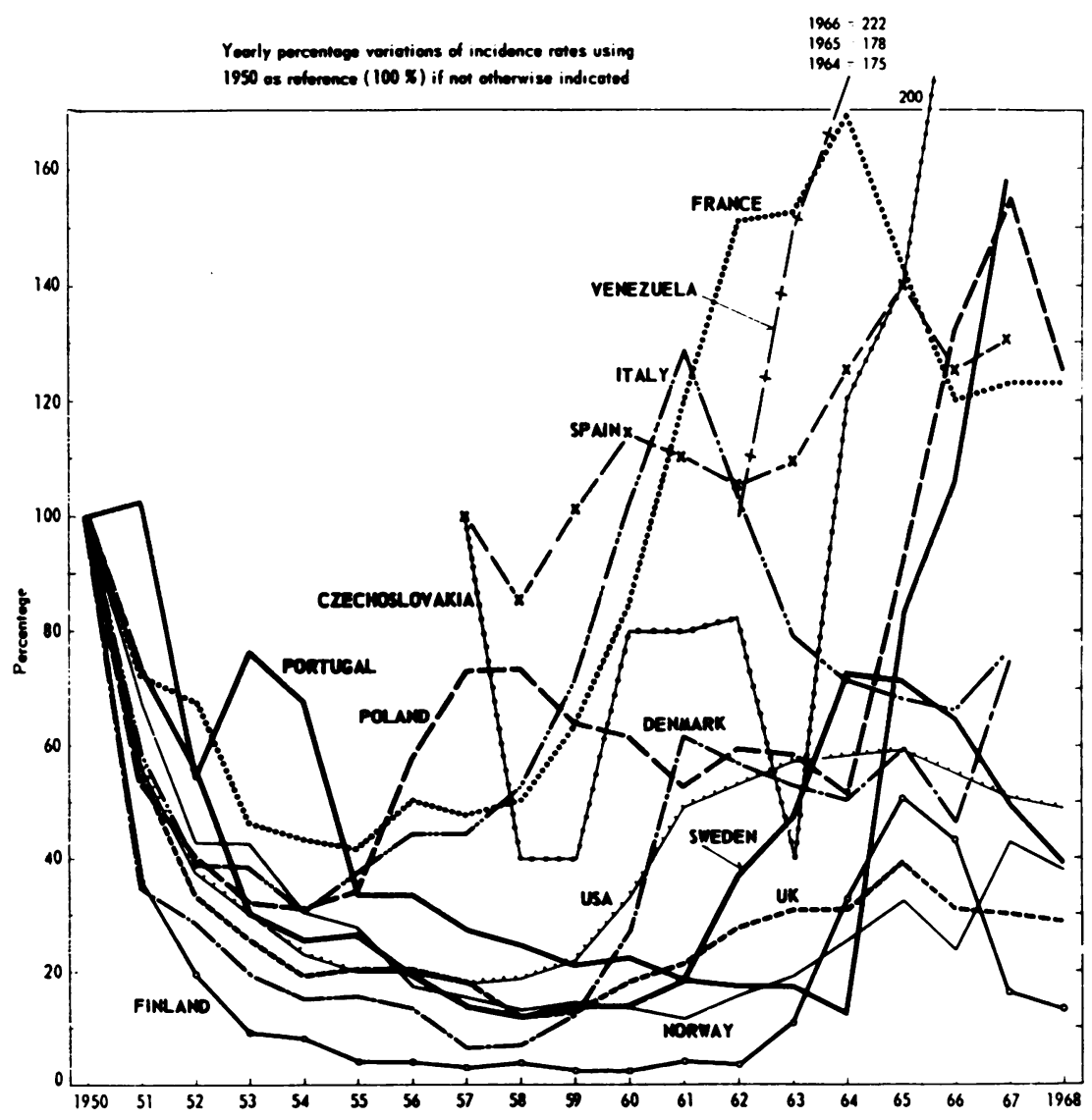

FIG. 1 Reported incidence of early syphilis in 13 countries, 1950-68 (From 'Today's VD Control Problem-1970', p. 46) 
statistics are available and of early congenital syphilis in nearly all areas (Fig. 2), but these offer the only rays of light in an otherwise sombre scene.

Millions of men and women suffer from gonorrhoea (currently estimated as 16 million cases annually (Guthe, 1972) although many more suffer from the condition (WHO, 1963)). The incidence is now mounting steeply in practically all areas, and the situation has been widely described as 'out of control' and an 'epidemic by any standards' (Fig. 3).

In the United Kingdom in 1969, for example, the increase in the incidence of gonorrhoea was 13.9 per cent. with a further 7 per cent. estimated for 1970 . In Denmark, as in Canada, there was an estimated 15 per cent. increase in 1970 . In Sweden the present rate is 485 per 100,000 (WHO, 1971), while in the U.S.A., when an allowance has been made for underreporting, the number of cases of gonorrhoea is currently considered to amount to 2 millions, corresponding to an annual incidence of 1 per cent. of the population, or one case every 15 seconds (Brown, 1971). The majority of these cases escape the contacttracing which is the mainstay of control because more than seven out of ten infections with gonorrhoea and primary and secondary syphilis are not reported (McKenzie-Pollock, 1970: Fig. 4, Table I).

TABLE I Reporting of infectious venereal disease in the U.S.A., 1968

(Data from McKenzie-Pollock, 1970)

\begin{tabular}{|c|c|c|}
\hline Disease & $\begin{array}{l}\text { Primary and } \\
\text { secondary syphilis }\end{array}$ & Gonorrhoea \\
\hline $\begin{array}{l}\text { Estimated number of cases } \\
\text { No. not reported }\end{array}$ & $\begin{array}{l}75,207 \\
55,025\end{array}$ & $\begin{array}{l}1,449,581 \\
1,018,201\end{array}$ \\
\hline Percentage not reported & $73 \cdot 2$ & $70 \cdot 2$ \\
\hline
\end{tabular}

\section{OTHER DISEASES}

This is by no means the full story; the problem of gonorrhoea is but a fraction of the whole, as many other sexually-transmitted diseases (Table II) caused by spirochaetes, bacteria, viruses, protozoa, fungi, and parasites, are not recorded at all in most countries. Other sexually-transmitted organisms are waiting in the wings, as it were, seeking a role.

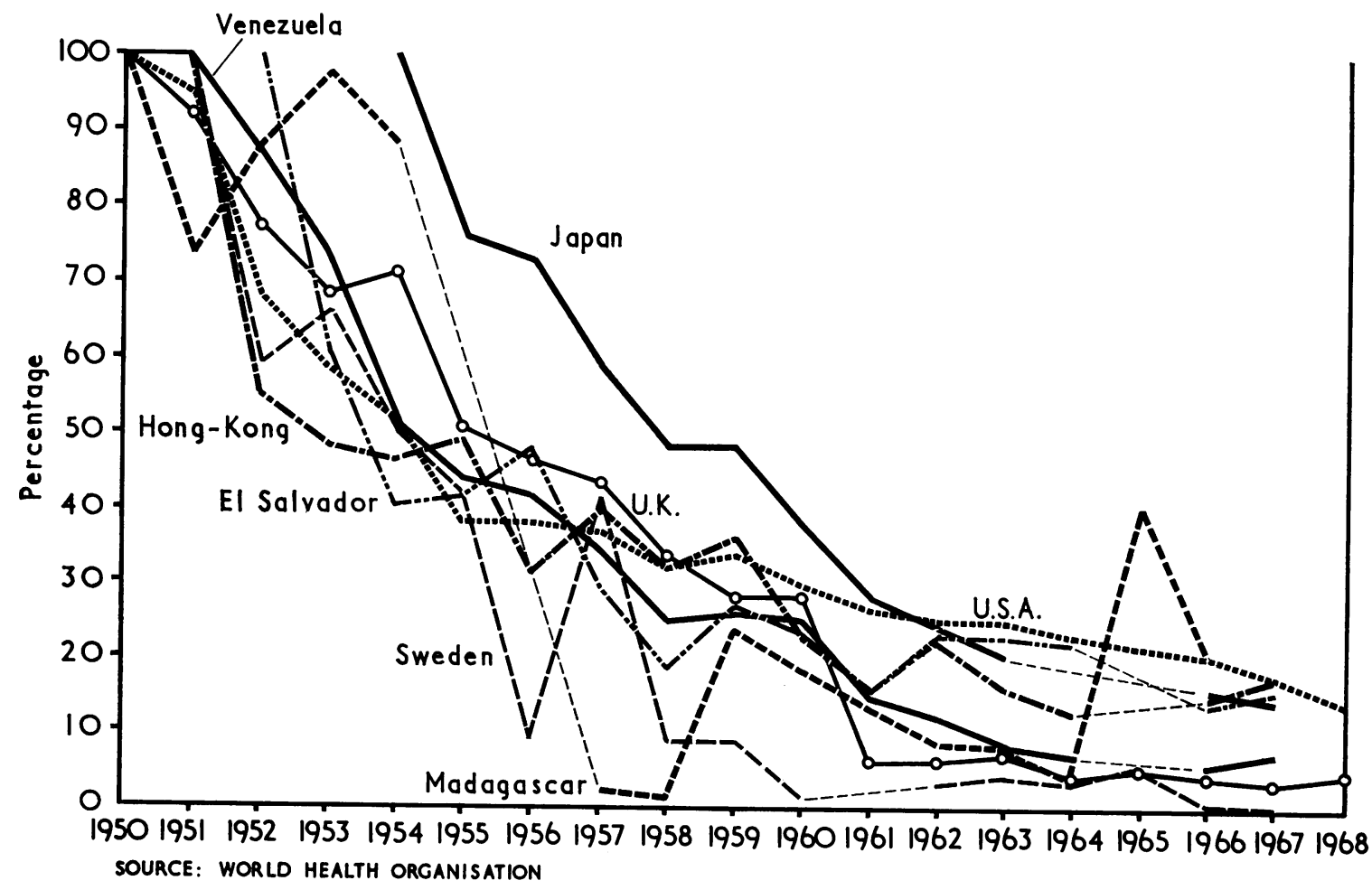

FIG. 2 Fall in incidence of congenital syphilis in eight countries, 1950-68 (From 'Today's VD Control Problem -1970, p. 47) 

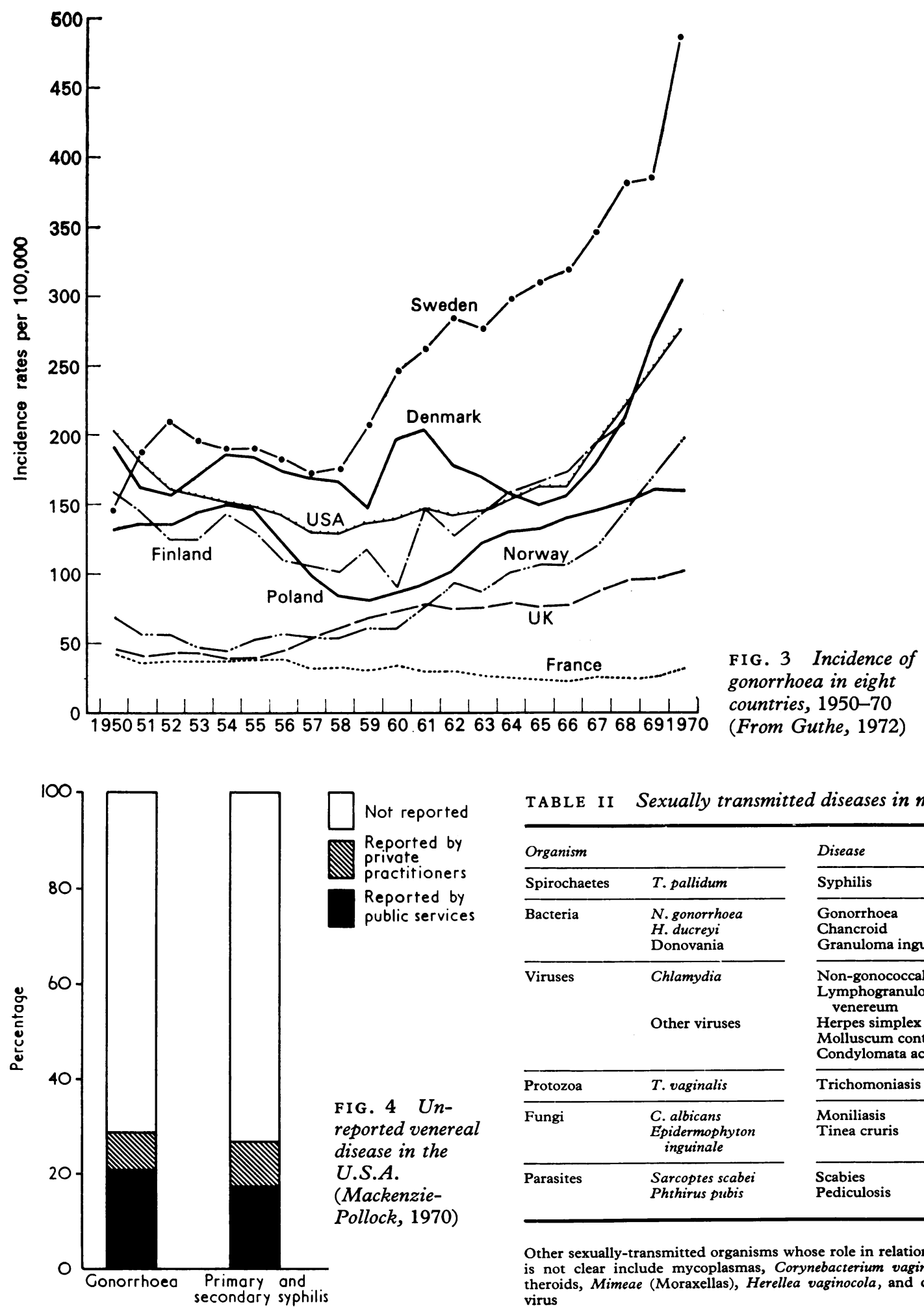

TABLE II Sexually transmitted diseases in man

Not reported

Reported by private practitioners

Reported by public services

FIG. 4 Unreported venereal disease in the U.S.A.

(MackenziePollock, 1970)

\begin{tabular}{llll}
\hline Organism & T. pallidum & & $\begin{array}{l}\text { Disease } \\
\text { Syphilis }\end{array}$ \\
\hline Bacteria & $\begin{array}{l}\text { N. gonorrhoea } \\
\text { H. ducreyi } \\
\text { Donovania }\end{array}$ & & $\begin{array}{l}\text { Gonorrhoea } \\
\text { Chancroid } \\
\text { Granuloma inguinale }\end{array}$ \\
\hline Viruses & Chlamydia & & $\begin{array}{l}\text { Non-gonococcal urethritis } \\
\text { Lymphogranuloma } \\
\text { venereum }\end{array}$ \\
\hline Protozoa & Other viruses & $\begin{array}{l}\text { Herpes simplex } \\
\text { Molluscum contagiosum } \\
\text { Condylomata acuminata }\end{array}$ \\
\hline Fungi & T. vaginalis & $\begin{array}{l}\text { C. albicans } \\
\text { Epidermophyton } \\
\text { inguinale }\end{array}$ & $\begin{array}{l}\text { Trichomoniasis } \\
\text { Moniliasis } \\
\text { Tinea cruris }\end{array}$ \\
\hline Parasites & $\begin{array}{l}\text { Sarcoptes scabei } \\
\text { Phthirus pubis }\end{array}$ & $\begin{array}{l}\text { Scabies } \\
\text { Pediculosis }\end{array}$ \\
\hline
\end{tabular}

Other sexually-transmitted organisms whose role in relation to disease is not clear include mycoplasmas, Corynebacterium vaginalis, diphtheroids, Mimeae (Moraxellas), Herellea vaginocola, and cytomegalic virus 
In England and Wales, where, unlike most countries, statistics relating to non-gonococcal urethritis in males have been recorded since 1951, the numbers of men with this condition now well exceed those of men with gonorrhoea (Fig. 5, Table III).

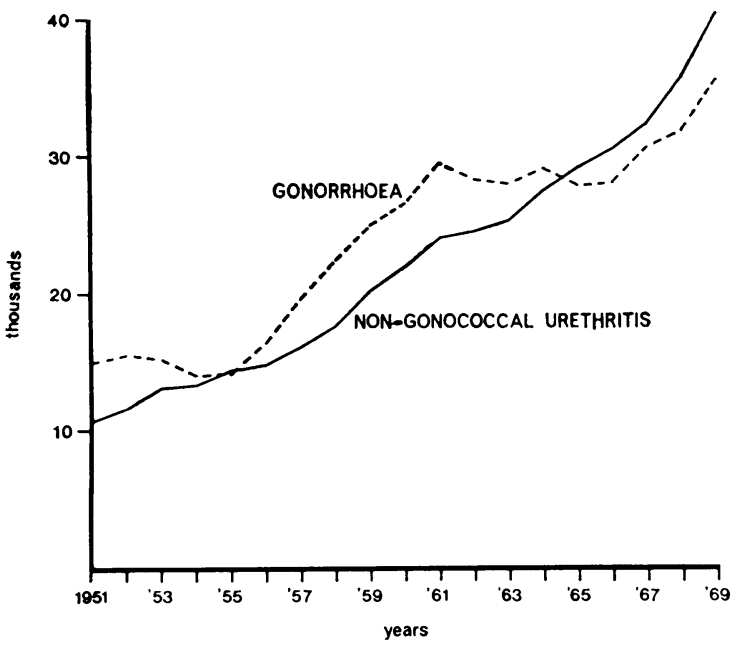

FIG. 5 Urethritis in males, 1951-69, in England and Wales

TABLE III Urethritis in males in England and Wales

(Department of Health and Social Security, 1969)

\begin{tabular}{llll}
\hline Year & & Gonorrhoea & Non-gonococcal urethritis \\
\cline { 1 - 1 } 1951 & 14,975 & & 10,794 \\
1954 & 13,962 & 13,279 \\
1955 & 14,079 & 14,269 \\
1956 & 16,377 & 14,825 \\
1961 & 29,519 & 24,472 \\
1965 & 27,886 & 29,141 \\
1966 & 27,921 & 30,462 \\
1967 & 30,648 & 32,318 \\
1968 & 31,838 & 35,721 \\
1969 & 35,519 & 40,320 \\
\hline
\end{tabular}

Patients with syphilis and gonorrhoea comprise only approximately one-quarter of males and one-fifth of females attending venereal disease clinics (Fig. 6 , Table IV).

\section{YOUNG PERSONS}

Venereal disease rates have sometimes risen more steeply in young persons than in the population as a whole (Rosenblatt and Kabasakalian, 1966). Not only are young women maturing earlier (the age at the menarche in Great Britain having fallen by 4 to 6 months per decade for the past 100 years-Wilson and Sutherland, 1960), but pre-pubertal infections are apparently becoming more common (Fiumara

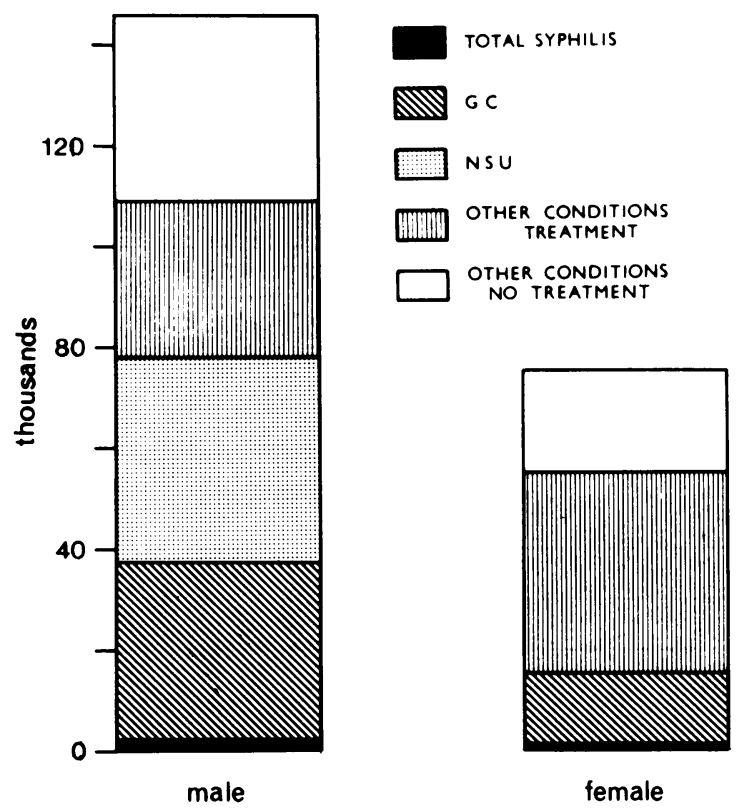

FIG. 6 Sexually transmitted diseases in England and Wales, 1969, by sex

TABLE IV Sexually transmitted (venereal) diseases treated in 195 V.D. clinics in England in 1969 (Department of Health and Social Security, 1969)

\begin{tabular}{|c|c|c|}
\hline \multirow{2}{*}{ Disease } & \multicolumn{2}{|l|}{ Sex } \\
\hline & Male & Female \\
\hline $\begin{array}{l}\text { Total syphilis } \\
\text { Chancroid }\end{array}$ & $\begin{array}{r}2,240 \\
53\end{array}$ & $\begin{array}{r}1,028 \\
3\end{array}$ \\
\hline Gonorrhoea & 35,519 & 14,518 \\
\hline Non-gonococcal urethritis & 40,320 & - \\
\hline Other conditions requiring treatment & 31,492 & 39,581 \\
\hline Other conditions requiring no treatment & 146,101 & 75,394 \\
\hline Total cases of syphilis or gonorrhoea & 37,759 & 15,546 \\
\hline Percentage with syphilis or gonorrhoea & $25 \cdot 8$ & $20 \cdot 1$ \\
\hline
\end{tabular}

and Briley, 1969; U.S. Center for Disease Control, 1970).

The phenomenon of venereal disease in the young has been observed to be associated with juvenile delinquency, illegitimacy, drug taking, and later in life with prostitution, while all these misfortunes have been related to a broken home life (Guthe and Willcox, 1971). As patients with venereal disease tend to contract more venereal disease in the future, methods of prevention in this group merit particular attention. Nevertheless the rises now being experienced affect all age groups (Fig. 7, opposite, and Table V, overleaf). 

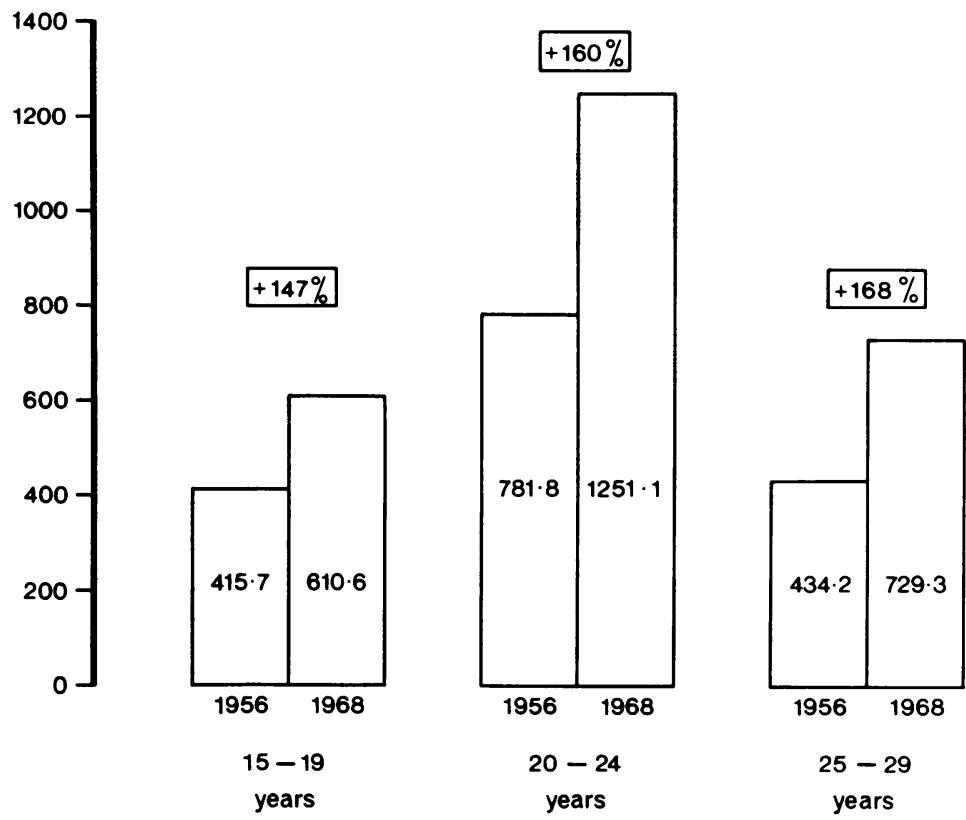

FIG. 7 Increase in gonorrhoea in the U.S.A., 1956-68, by age group

TABLE VI Reasons for failure of control of venereal disease

\begin{tabular}{|c|c|c|}
\hline \multirow[t]{2}{*}{ Demographic factors } & (a) More susceptibles & Increasing population; relatively more young people \\
\hline & (b) Longer individual sexual span & $\begin{array}{l}\text { Longer life; earlier maturity; 'dispensation' of menopause by } \\
\text { hormones }\end{array}$ \\
\hline \multirow{4}{*}{ Medical factors } & (b) No decisive new advance in diagnosis & $\begin{array}{l}\text { Too little research. No quick screening test without genital } \\
\text { examination (particularly in asymptomatic female) capable of } \\
\text { detecting gonorrhoea before disease has been passed on }\end{array}$ \\
\hline & (c) Increasing failure rates to treatment & Development of resistance of the gonococcus to antibiotics \\
\hline & (d) Lack of immunizing procedure & Multiple attacks \\
\hline & (e) Strained facilities & $\begin{array}{l}\text { Insufficient money spent on premises, medical and ancillary staff, and } \\
\text { contact-tracers }\end{array}$ \\
\hline
\end{tabular}


TABLE $\mathrm{V}$ Reported venereal disease in the U.S.A. (Case rates per 100,000 - A.S.H.A., 1970)

\begin{tabular}{|c|c|c|c|c|}
\hline \multirow{2}{*}{$\begin{array}{l}\text { Age group } \\
\text { (yrs) }\end{array}$} & \multicolumn{2}{|c|}{$\begin{array}{l}\text { Primary and secondary } \\
\text { syphilis }\end{array}$} & \multicolumn{2}{|c|}{ Gonorrhoea } \\
\hline & 1956 & 1968 & 1956 & 1968 \\
\hline $\begin{array}{l}15-19 \\
20-24 \\
25 \text { and over }\end{array}$ & $\begin{array}{r}10 \cdot 7 \\
18 \cdot 4 \\
3 \cdot 6\end{array}$ & $\begin{array}{r}19 \cdot 3 \\
38 \cdot 8 \\
9 \cdot 4\end{array}$ & $\begin{array}{l}415 \cdot 7 \\
781 \cdot 8 \\
106 \cdot 9\end{array}$ & $\begin{array}{r}610 \cdot 6 \\
1,251 \cdot 1 \\
165 \cdot 6\end{array}$ \\
\hline All ages & 3.9 & $9 \cdot 6$ & $135 \cdot 7$ & $235 \cdot 1$ \\
\hline
\end{tabular}

\section{Reasons for failure of control}

Many interwoven factors are concerned-demographic, socio-economic, behavioural, and medical (Table VI, p. 167) - and these are related to changes in the environment, in the host, and in the responsible organisms.

\section{CHANGES IN THE ENVIRONMENT}

Demographic factors

These include more susceptible subjects because of the increasing numbers of young people and the longer sexual life span resulting from earlier maturity and increased longevity.

The world population increased by approximately 225 millions during each of the decades 1930-1940

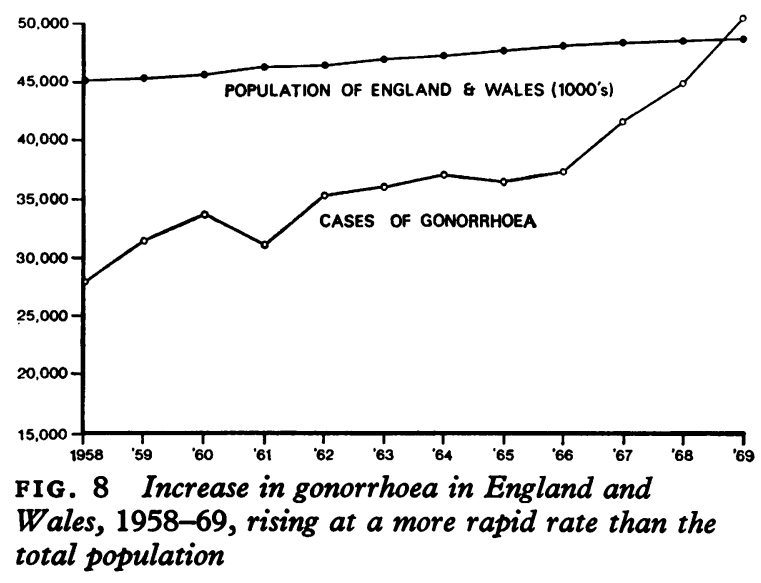

TABLE VII Increase in cases of gonorrhoea reported in U.S.A. related to population increase

\begin{tabular}{|c|c|c|}
\hline Year & Population & Cases of gonorrhoea \\
\hline $\begin{array}{l}1956 \\
1968\end{array}$ & $\begin{array}{l}165,341,000 \\
197,571,000\end{array}$ & $\begin{array}{l}224,683 \\
464,543\end{array}$ \\
\hline Increase & $32,230,000$ & 239,860 \\
\hline Percentage increase & $19 \cdot 5$ & $106 \cdot 8$ \\
\hline
\end{tabular}

Figures from A.S.H.A. (1970) and 1940-1950; the rise was 500 millions between 1950-1960 and a further rise of 700 millions was expected by the end of 1970 (United Nations, 1967).

However, data from many countries, including the United Kingdom (Fig. 8) and the U.S.A. (Table VII), indicate that the increased population accounts for only a small part of the increase in gonorrhoea.

\section{Socio-economic factors}

As a result of so-called progress, population mobility due to industrialization, urbanization (although disease from the towns can spread to the country, as noted in New Zealand by Loughlin, 1969), more female employment, migration of labour both internationally and within countries (immigrant groups have always shown higher venereal disease rates than the home population - Willcox, 1970a), and holiday and business travel (Guthe and Idsøe, 1968) (Table VIII) has multiplied opportunities for sexual encounter and has also tended to introduce venereal disease into previously 'closed' circles in the static population.

TABLE VIII Indices of increased travel

\begin{tabular}{|c|c|c|c|}
\hline Year & $\begin{array}{l}\text { World air } \\
\text { travel } \\
\text { passengers } \\
\text { carried } \\
\text { (millions) }\end{array}$ & $\begin{array}{l}\text { International } \\
\text { tourism } \\
\text { arrivals in } \\
26 \text { countries } \\
\text { (millions) }^{2}\end{array}$ & $\begin{array}{l}\text { World } \\
\text { shipping } \\
\text { tonnage } \\
\text { (millions) }\end{array}$ \\
\hline $\begin{array}{l}1958 \\
1968\end{array}$ & $\begin{array}{r}88 \\
261\end{array}$ & $\begin{array}{r}55 \\
141\end{array}$ & $\begin{array}{l}118 \\
194\end{array}$ \\
\hline $\begin{array}{l}\text { Percentage } \\
\text { increase }\end{array}$ & 197 & $156^{3}$ & 65 \\
\hline
\end{tabular}

${ }^{1}$ By members of ICAO only (ICAO Bulletin, 1969)

'Tourism International Bureau, Geneva (1967). See Idsøe and Guthe (1967)

'Provisional

¿Lloyd's Register (1969) Statistical Tables

Particularly high rates of venereal disease have always been noted amongst the more mobile sections of the community; traditionally these included seamen (Guthe and Idsøe, 1964) and soldiers serving overseas, but in more recent times businessmen, actors, journalists, television technicians and longdistance truck drivers have become involved, and in particular holiday-makers, whose promising package tour is sometimes found to provide an unexpected and unwelcome 'packet'.

These changes will continue to increase and will further aggravate the venereal disease situation in the future.

\section{CHANGES IN THE HOST}

Physical changes

Apart from better nutrition which may have conferred greater resistance to the venereal (and other) 
diseases, improved social conditions, hygiene, and sanitation have reduced the numbers of cases of non-sexually acquired syphilis (although cases have been encountered in modern flats in which overcrowding has been encouraged by the tenants to save money to provide modern electronic luxuries Luger, 1970). In developed countries, these improvements have practically removed chancroid from a position of importance amongst venereal diseases, but these gains are more than offset by the effects on other venereal diseases of the behavioural changes which have occurred.

\section{Changes in attitude}

Changes in behavioural codes since 1945 have been endorsed or prompted by changes in attitude leading to the so-called 'permissive society', which often gives emphasis to indiscriminate heterosexual and homosexual intercourse. The attention given to sex by the mass media has created a vicious circle, so that the overt interest in sex in the home, office, shop floor, and school has encouraged further attention to it on the mass media.

At the same time the restraining influences of religion, family, and public opinion have diminished (Fig. 9), so that we have more divorces and broken homes, and higher illegitimacy rates. The fear of venereal disease has been reduced by the availability of simple effective treatments, which have led to the common problem of the 'chronic repeater'. The introduction of the contraceptive pill and the intrauterine device, which (unlike the condom which they are rapidly replacing) offer no protection against the venereal diseases, has lessened the fear of pregnancy.

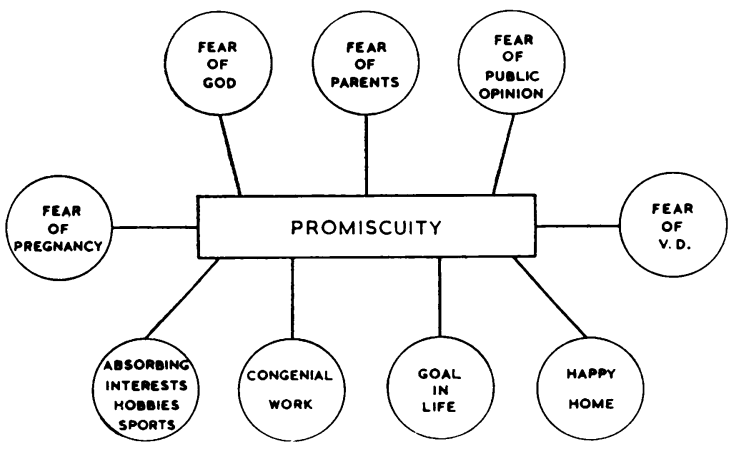

FIG. 9 Restraints on promiscuity

\section{Changes in sexual behaviour}

The influence of sex films and other such shows makes it reasonable to believe that sexual practices have changed. More homosexual patients have been reported in many venereal disease clinics, so that men with early syphilis (e.g. in Sweden, Denmark,
France, Britain, Hungary, and the U.S.A. - Guthe and Willcox, 1971) may comprise 10 to 90 per cent. of such cases (Price, 1969). Rectal infections with gonorrhoea are more difficult to cure than urethral infections (Fluker and Hewitt, 1970).

Many authors (e.g. Jensen, 1953; McClone, Scotti, Mackey, and Hackney, 1968; Schmale, Martin, and Domescik, 1969) have frequently found rectal gonorrhoea in women with urethral and cervical infections. Although some (e.g. Jensen, 1953) have suggested that peno-anal coitus was the predominant cause, the majority of observers have considered that such infections in the female usually arise from the transfer of infected material by the careless use of toilet paper.

There have recently been reports of oral infections by the gonococcus, an organism traditionally believed to be unlikely to affect the mouth. Such cases have included infections of the pharynx causing either sore throat (Fiumara, Wise, and Many, 1967) or no symptoms at all (Thatcher, McCraney, Kellogg, and Whaley, 1969), and of the tongue causing ulceration (Cowan, 1969). A possible increase in peno-oral contact does not yet seem to be of epidemiological importance. More than 50 years ago (see Cowan, 1969), it was suggested that colonization of the mouth might be a temporary phenomenon which could explain cases in which the source of genital infection was inapparent after contact investigation.

Other behavioural changes concern the altered patterns of prostitution which have followed the official suppression of brothels and prostitution in the classical sense, although in recent years modernized brothels have re-opened in some areas (e.g. the 'Eros' centres in Hamburg and the 'Ranch Houses' near Las Vegas).

\section{Changes in contraceptive practices}

Technological progress has resulted in improved contraceptives but these offer no protection against venereal disease and also promote promiscuity. When young persons of 20 years of age or under have been put on the pill, the number of sexual partners and the frequency of sexual intercourse have increased (Juhlin and Lidén, 1969). In the clinics more women using oral contraceptives are found among patients with gonorrhoea (Hewitt, 1970) and the incidence of gonorrhoea is markedly increasing among such persons (Cohen, 1970).

Today an estimated $17 \frac{1}{2}$ million women in western societies are on the pill (Population Council, 1969): 1.5 millions of them are to be found in Great Britain alone (Table IX, overleaf) and the figures continue to mount steeply (Fig. 10, overleaf). These adverse influences of modern contraceptives on venereal 
TABLE IX Estimated number of contraceptive 'pill' users in the United Kingdom *

\begin{tabular}{lc}
\hline Year ending December & No. of 'pill' users \\
1961 & 3,000 \\
1962 & 27,000 \\
1963 & 120,000 \\
1964 & 280,000 \\
1965 & 500,000 \\
1967 & 950,000 \\
1968 & $1,240,000$ \\
1969 & $1,500,000$ \\
\hline
\end{tabular}

$\star$ Data from P. M. Brown, Medical Department, G. D. Searle \& C $c^{\prime}$ Ltd., High Wycombe, Bucks., England

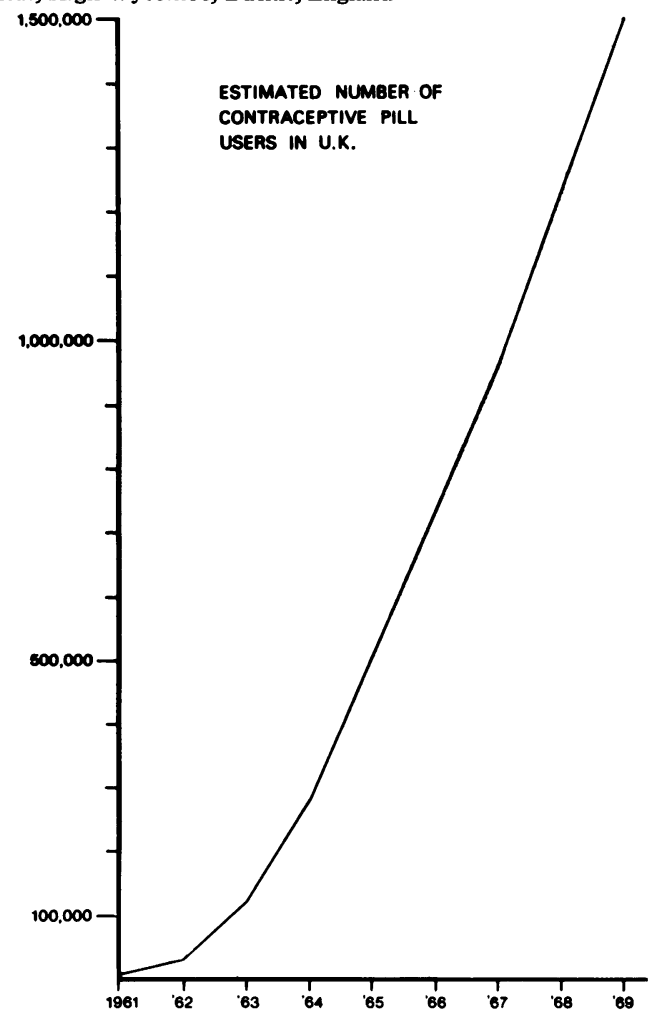

FIG. 10 Estimate numbers of users of the contraceptive pill in the United Kingdom, 1961-69

disease control are likely to increase even further in the future.

\section{Limitations of health education}

Venereal infections have been classified as 'behavioural' diseases (Burton, 1968) and should, in theory, be capable of being influenced if human behaviour can be influenced.

There is widespread ignorance of the venereal diseases, particularly amongst the young (Many, Reboul, Lapeyre, Boutet, Teillard, Jeanpierre, and Saliba, 1967; King, 1970; Dalzell-Ward, 1970), and members of the medical profession are often poorly educated in venereal disease control (Webster, 1966, 1970b).

Although it has been shown that those who gain information about venereal disease in school are quicker than others to seek advice when they believe they have contracted an infection (American Social Health Association, 1968), it is admitted that it is difficult to change established norms of behaviour. A full understanding of the dangers involved is certainly not sufficient, as is shown by statistics concerning cigarette smoking (Table $\mathrm{X}$ ) and by the extremely high rates of venereal disease which have been reported amongst the best educated and most intelligent members of any community, such as university students in Africa (Arya and Bennett, 1967) and Sweden (Juhlin and Wallin, 1972).

TABLE X Figures demonstrating the limitations of health education

Cigarette consumption in 26 countries (Cigarettes per adult per year) *

\begin{tabular}{|c|c|c|c|c|}
\hline \multirow{2}{*}{ Country } & \multicolumn{3}{|l|}{ Year } & \multirow{2}{*}{$\begin{array}{l}\text { Percent- } \\
\text { age rise } \\
(1956 \text { to } \\
1966)\end{array}$} \\
\hline & 1946 & 1956 & 1966 & \\
\hline Spain & 540 & 700 & 1,800 & $+157 \cdot 1$ \\
\hline W. Germany & - & 1,210 & 2,200 & +81.8 \\
\hline Belgium & 970 & 1,320 & 2,070 & +56.8 \\
\hline Japan & 310 & 1,600 & 2,440 & +52.5 \\
\hline Australia & 650 & 1,880 & 2,760 & +46.8 \\
\hline Italy & 660 & 1,120 & 1,640 & +46.4 \\
\hline New Zealand & 1,220 & 1,750 & 2,530 & +44.6 \\
\hline Canada & 1,690 & 2,480 & 3,450 & $+39 \cdot 1$ \\
\hline Sweden & 600 & 1,020 & 1,400 & $+37 \cdot 3$ \\
\hline Austria & 410 & 1,440 & 1,930 & +34.0 \\
\hline Denmark & 690 & 1,180 & 1,550 & $+31 \cdot 4$ \\
\hline Greece & 1,200 & 1,530 & 2,010 & $+31 \cdot 4$ \\
\hline Switzerland & 1,260 & 1,860 & 2,400 & +29.0 \\
\hline Iceland & 1,860 & 1,570 & 1,980 & +26.1 \\
\hline France & 590 & 1,240 & 1,560 & +25.8 \\
\hline Turkey & 1,250 & 1,580 & 1,900 & $+20 \cdot 3$ \\
\hline U.S.A. & 3,050 & 3,370 & 3,850 & $+14 \cdot 2$ \\
\hline U.K. & 2,600 & 2,530 & 2,810 & $+11 \cdot 1$ \\
\hline Eire & 1,970 & 2,510 & 2,770 & +10.4 \\
\hline Norway & 540 & 520 & 540 & $+\quad 3.8$ \\
\hline
\end{tabular}

Reduced consumption 1956-1966 was reported only by Argentina, Brazil, Finland, Netherlands, Mexico, and South Africa ^Beese (1968)

Advertisers have little trouble in persuading the public that a product is desirable if it fulfils a need; perhaps if the money were forthcoming and the campaign properly sponsored, the desirability of maintaining 'positive venereal health' by restricting sexual contacts might be instilled into those who are sexually active and something worth while might thus be achieved. Recent experience in the United Kingdom indicates that a television presentation can have an enormous impact on the age-groups concerned if the material is put over forcefully. 
CHANGES IN THE ORGANISMS

\section{? Lowered virulence}

There is some suggestion that, under chemotherapeutic and antibiotic bombardment, both syphilis and gonorrhoea are becoming milder diseases, but as regards syphilis better nutrition and improved personal hygiene may be responsible for the fact that fewer exuberant lesions (e.g. condylomata lata) are seen nowadays.

Certainly some patients regard gonorrhoea as less important than a cold and asymptomatic infections are now more commonly encountered in males (Pariser, Farmer, and Marino, 1964); some asymptomatic cases in both sexes may show mild septicaemic lesions (Abu-Nasser, Hill, Fred, and Yow, 1963; Barr and Danielsson, 1971).

Centuries hence, if this process were carried to a conclusion, the gonococcus might become a nonpathogenic commensal, but this does not help the immediate situation. Gonorrhoea is becoming more difficult to control in both sexes and it is now more important that male contacts of infected females should also be examined, because infected men can no longer be expected to report with obvious and uncomfortable symptoms.

Furthermore, in patients with syphilis, treponemal forms have been found to persist in the lymph nodes, cerebrospinal fluid, and aqueous humour despite 'adequate' treatment (Collart, Borel, and Durel, 1962; Yobs, Clark, Mothershed, Bullard, and Artley, 1968; Smith and Israel, 1967). The significance of these organisms is not yet clear, and it is possible that some are not syphilitic treponemes; or they may be $T$. pallida but of lessened virulence.

\section{Increased resistance}

The developing resistance of the gonococcus to antibiotics, particularly penicillin, is not in dispute. This phenomenon is not apparent in relation to $T$. pallidum but our inability to culture this organism in vitro makes a precise testing of this point impracticable (Schamberg, 1963).

Even making allowances for differences in methods of assessment and reporting, and by selecting only

TABLE XI Sensitivity of the gonococcus to penicillin Percentage minimum inhibitory concentration ( $\mu \mathrm{g} . / \mathrm{ml}$.)

\begin{tabular}{|c|c|c|c|c|c|}
\hline \multirow{2}{*}{ Area } & \multirow{2}{*}{ Authors } & \multirow{2}{*}{ Date } & \multicolumn{3}{|c|}{ Percentage $M I C(\mu \mathrm{g} . / \mathrm{ml})}$. \\
\hline & & & 0.05 or less & $0 \cdot 06-0 \cdot 12$ & $<0.12$ \\
\hline \multicolumn{6}{|l|}{ EUROPE } \\
\hline U.K. (London) & Lynn and others & 1970 & $65 \cdot 0$ & $18 \cdot 5$ & 16.5 \\
\hline & Leigh and others & 1969 & $63 \cdot 0$ & $18 \cdot 0$ & $19 \cdot 0$ \\
\hline Norway & Gundersen and others & 1969 & $65 \cdot 5$ & $17 \cdot 8$ & $16 \cdot 7$ \\
\hline \multicolumn{6}{|l|}{ NORTH AMERICA } \\
\hline Canada & Amies & 1969 & 34.9 & $19 \cdot 0$ & $46 \cdot 1$ \\
\hline U.S.A. & $\begin{array}{l}\text { Fischnaller, Pedersen, Ronald, Bonin, and } \\
\text { Tronca }\end{array}$ & 1968 & $20 \cdot 9$ & $22 \cdot 4$ & $56 \cdot 7$ \\
\hline AUSTRALIA & Hatos & 1970 & $22 \cdot 0$ & $6 \cdot 8$ & $71 \cdot 2$ \\
\hline \multicolumn{6}{|l|}{ AFRICA } \\
\hline Uganda & Arya and Phillips & 1970 & $19 \cdot 1$ & $7 \cdot 5$ & $73 \cdot 4$ \\
\hline $\begin{array}{l}\text { FAR EAST } \\
\text { Hawaii, Japan, Philippines }\end{array}$ & Keys, Halverson, and Clarke & 1969 & $14 \cdot 5$ & $11 \cdot 6$ & 73.9 \\
\hline
\end{tabular}

TABLE XII Percentage incidence of most resistant gonococci (MIC $0.5 \mu \mathrm{g} . / \mathrm{ml}$. or more)

\begin{tabular}{|c|c|c|c|c|}
\hline Country & Authors & Date & No. of strains examined & $\begin{array}{l}\text { Percentage } \\
\text { MIC } 0.5 \mu \mathrm{g} . / \mathrm{ml} \text {. or more }\end{array}$ \\
\hline Uganda & Arya and Phillips & 1970 & 173 & nil \\
\hline Sweden & Enfors and Molin & 1970 & 145 & 0.7 \\
\hline U.K. & Lynn and others & 1970 & 97 & $4 \cdot 1$ \\
\hline Norway & Gundersen and others & 1969 & 1,000 & $6 \cdot 4$ \\
\hline U.K. & Leigh and others & 1969 & 100 & $10 \cdot 0$ \\
\hline Canada & Amies & 1969 & 1,976 & $18 \cdot 6$ \\
\hline Hawaii & Keys and others & 1969 & 30 & $30 \cdot 0$ \\
\hline Canada & Ronald, Eby, and Sherris & 1969 & 94 & $37 \cdot 0$ \\
\hline Philippines & Keys and others & 1969 & 179 & $44 \cdot 7$ \\
\hline Australia & Hatos & 1970 & $?$ & $45 \cdot 8$ \\
\hline U.S.A. & Fischnaller and others & 1968 & 67 & $56 \cdot 7$ \\
\hline Japan & Keys and others & 1969 & 33 & $57 \cdot 6$ \\
\hline
\end{tabular}




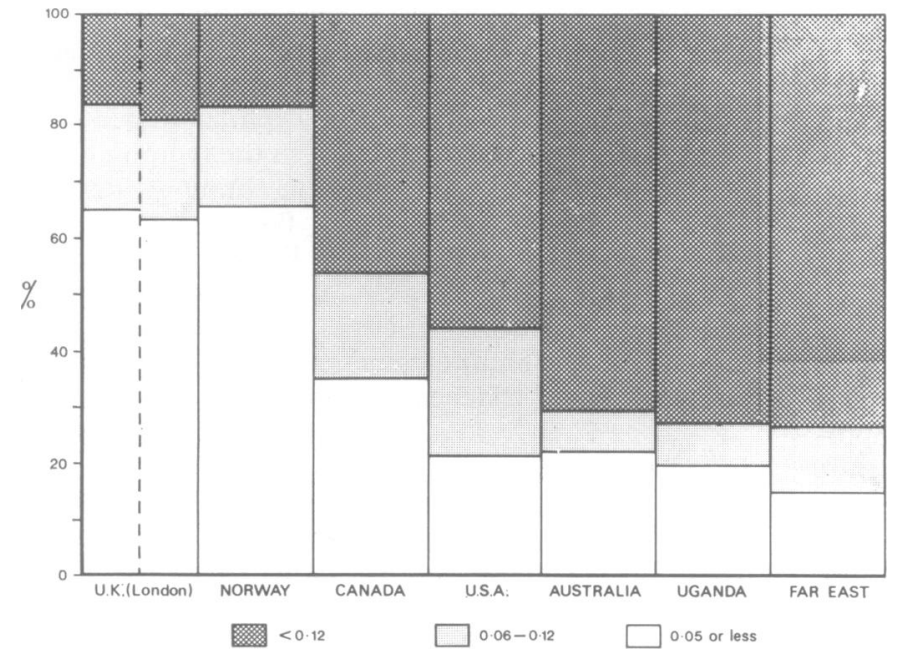

FIG. 11 Sensitivity of the gonococcus to penicillin in seven areas of the world data referring to routine and not to problem strains of gonococci, the distribution of the more resistant organisms is found to be patchy as between continents (Tables XI and XII; Fig. 11, overleaf), the situation in Africa and the Far East, for example, being far worse than that in northern Europe (Reyn, 1969). Moreover, differences are also noted in different parts of the same continent, and even in different parts of the same country (Thayer, Samuels, Martin, and Lucas, 1965); the gonococcus is apparently more resistant, for example, in San Francisco than in Philadelphia.

Particularly marked in the Far East, near the present and past war zones, it is evident that such resistance builds up most quickly where two fairly 'closed' promiscuous groups are having repeated sexual exchanges over long periods of time. With high rates of promiscuity, there is a high level of feedback of resistant organisms from male cases which have failed to be cured by penicillin to the female reservoir (Willcox, 1965). Such resistant organisms, when subsequently introduced into the civilian population, as with the 'hospital' staphylococcus, tend to become 'diluted' even if prostitutes are still involved (WHO, 1968; Fig. 12, opposite).

This process of increasing resistance has been shown to be capable of being checked, e.g. in Canada (Amies, 1969) and in the United Kingdom (Leigh, LeFranc, and Turnbull, 1969; Lynn, Nicol, Ridley, Rimmer, Symonds, and Warren, 1970), or even reversed as in Denmark (Nielsen, 1970), Greenland (Olsen and Lomholt, 1969), and Norway (Gundersen, Odegaard, and Gjessing, 1969).

Nevertheless, the continuing trend towards more and more resistance is generally upwards, e.g. in the U.S.A., the United Kingdom (Nicol, Ridley, and
Symonds, 1968), France (Durel, Roiron, and Nicod, 1967), and Australia (Smith and Levey, 1967).

This has necessitated bigger and bigger doses of penicillin if the disease is to be cured by a single injection. The 'one-shot' doses required today (e.g. 4.8 million units for women) represent almost the full capacity of the female buttock, and even this dose has been shown to fail in about 30 per cent. of cases in some parts of the world (WHO, 1968).

This situation is being countered by the use of multiple doses of penicillin (Wren, 1967), or by the other more expensive antibiotics of which there is now a considerable number (Table XIII, opposite).

The effective antibiotics which are now being discovered about keep pace with the deteriorating situation, but it is by no means certain that such will always be so, and continuing research is therefore required. In the meantime the useful life of the relatively cheap non-toxic penicillin given by single injection is being prolonged by the use of probenecid (Lomholt and Berg, 1966; Holmes, Johnson, and Floyd, 1967; Willcox, 1970a; Cobbold, Morrison, Spitzer, and Willcox, 1970).

\section{Future outlook}

Although the physician and the scientist have done their best to provide swift, safe and easy diagnosis and treatments, their efforts have been swamped by the effects of human behaviour. The likelihood of further population mobility, continuing permissiveness, increasing use of oral contraceptives, and wider promiscuity, together with the further resistance of the gonococcus to antibiotics requires some radical development to reverse the situation.

Effective vaccines against these diseases are still far away, although some immunity has been established 


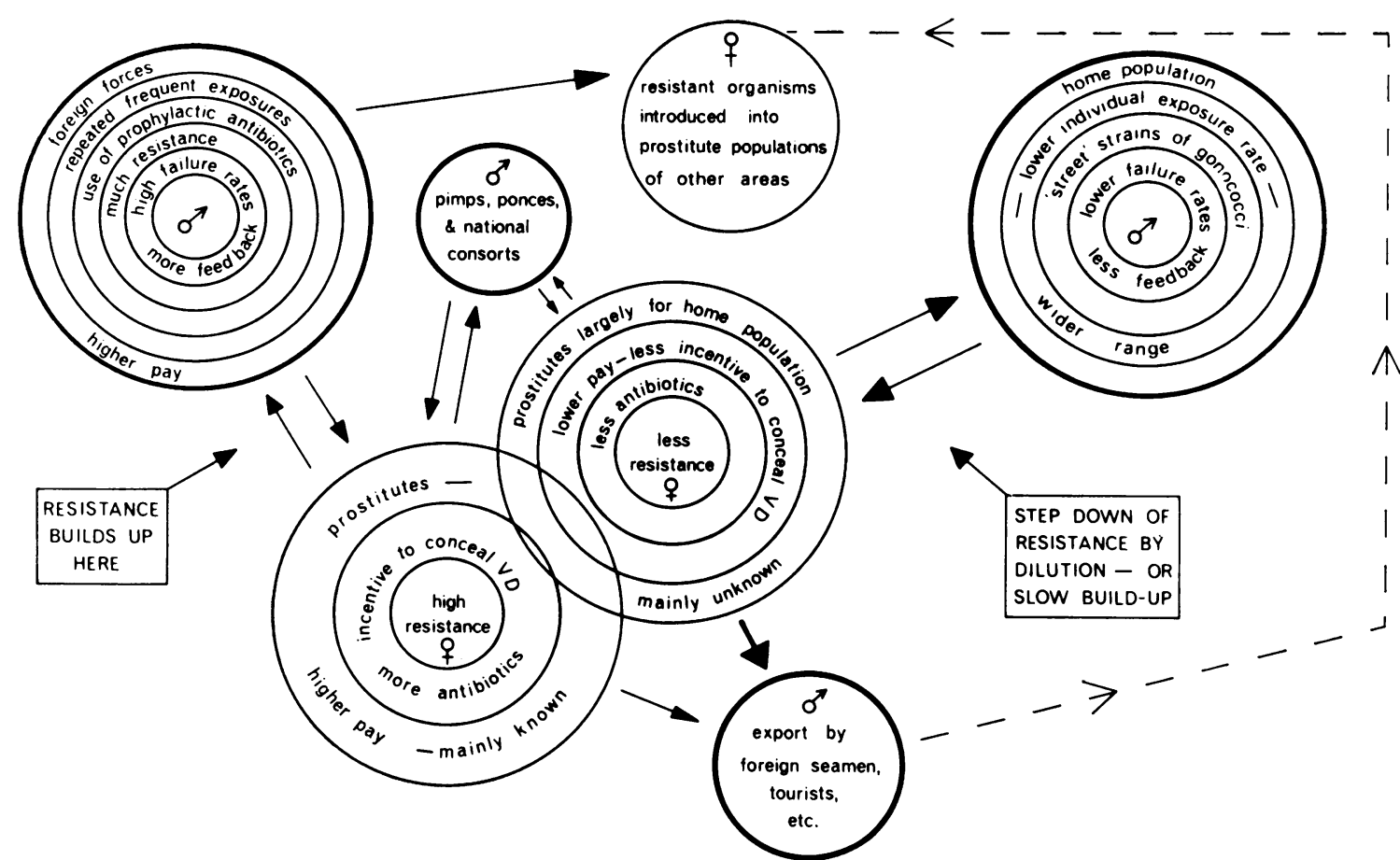

FIG. 12 Build-up of resistance of the gonococcus to penicillin in the Far East

TABLE XIII Antibiotics used in the treatment of gonorrhoea

\begin{tabular}{|c|c|}
\hline INYECT ABLE PREPARATIONS & $\begin{array}{l}\text { Crystalline benzyl penicillin G; aqueous procaine penicillin; mixtures of crystalline and } \\
\text { procaine penicillin; repository penicillins }{ }^{1} \text { as PAM, benzathine, and benethamine } \\
\text { penicillin or mixtures containing them, ampicillin, hetacillin, carbenecillin, and } \\
\text { cephalosporins synnematin B and cephaloridine } \\
\text { The penicillinase-resistant penicillins are relatively ineffective } \\
\text { Injectable tetracyclines including rolitetracycline, chloromycetin succinate, }{ }^{2} \\
\text { kanamycin, spectinomycin }{ }^{5} \text {, and streptomycin }{ }^{3}\end{array}$ \\
\hline ORALLY ADMINISTERED PREPARATIONS & $\begin{array}{l}\text { Phenoxymethyl penicillin (V), phenethicillin, ampicillin, hectacillin, amoxycillin, } \\
\text { pirampicillin, panamecillin, and the cephalosporin cephalexin } \\
\text { Chlortetracycline, oxytetracycline, tetracycline hydrochloride and phosphate complex, } \\
\text { limecycline, methacycline, clomocycline, doxycycline, minocycline, mixed tetracyclines } \\
\text { Chloramphenicol and its analogue thiamphenicol, erythromycin, spiramycin, } \\
\text { pristinomycin, hetacillin, rifampicin } \\
\text { Sulphonamides with and without trimethoprim }\end{array}$ \\
\hline
\end{tabular}

${ }^{1}$ Not recommended as likely to foster developing resistance

'Not recommended on grounds of toxicity

${ }^{3}$ Not recommended on account of resistance

'Not reported upon

${ }^{5}$ Not commercially available for gonorrhoea in all countries

Note: Serum levels of all penicillin and cephalosporin preparations can be enhanced and prolonged by the use of probenecid. Those effective in a single dose are in italics

against syphilis in rabbits by many repeated injections of killed (Metzger, Michalska, Podwińska, and Smogór, 1969) or irradiated (Miller, Bekker, DeBruijn, and Onvlee, 1969) treponemes. Some antibodies are also detectable in most cases of gonorrhoea, but there is little evidence that they are protective. However, recent developments against the meningococcus (Goldschneider, Gotschlich, and
Artenstein, 1969; Gotschlich, Teh Yung Liu, and Artenstein, 1969) have revived interest in this matter.

The more optimistic draw attention to the fact that syphilis, because of its long incubation period, is more amenable to control by contact-tracing than gonorrhoea and the other venereal diseases because of the availability of screening blood tests. Heretofore there has been no satisfactory serological test for gonor- 
TABLE XIV Results of routine screening of females for gonorrhoea

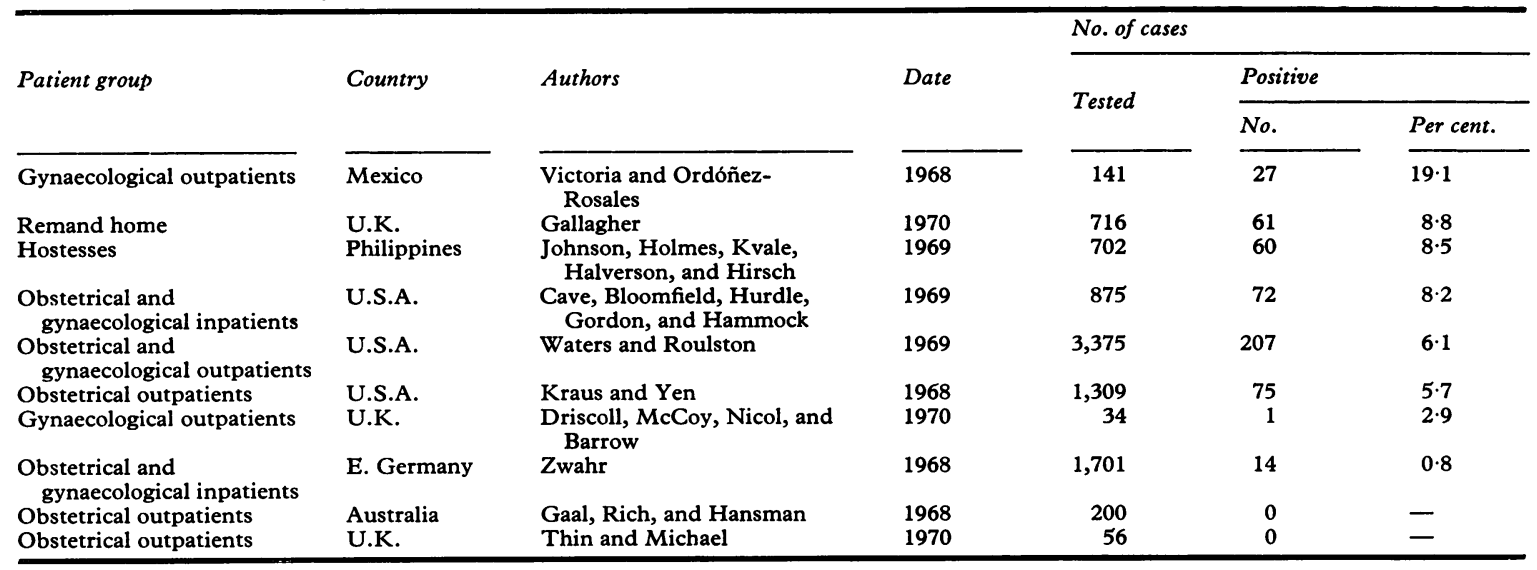

rhoea which can be used to detect the asymptomatic female who represents the reservoir of infection. Available routine tests using genital smears and cultures are most conveniently done on antenatal and gynaecological patients and when so performed have shown varying results depending on the methods used and the sites tested (Table XIV). Nevertheless, as recommended by Brown (1970), it seems desirable that this practice be extended.

The availability of a reliable and sensitive serum test for gonorrhoea would provide an advance of some magnitude as it could be widely applied for screening purposes. The original gonococcal complementfixation reaction either seldom produced a positive result in early cases in males, in whom it was commonly believed that systemic antibodies were frequently not formed in an essentially local infection, or it gave false-positive results either because other Neisseria were present or for no apparent reason. It has now been shown that systemic gonococcal antibodies are produced even in infections in men and that these can be detected by one or more of several possible new techniques (Table XV). Thus a reason- ably satisfactory serum test for gonorrhoea may be available during the next few years, although if seropositivity persists for long periods in the treated case, this will limit its usefulness.

In the meantime the physician-although he should not moralize - should make the point that the general population cannot have their cake and eat it: if they wish to keep changing their sexual consorts, particularly with group sexual activity, some venereal infection is inevitable, no longer sooner or later but sooner.

Maybe, if the expertise of Madison Avenue were enlisted to concentrate on this point on television and other mass media, such a campaign would have some impact. Certainly, amongst the groups concerned, even a partial return to the philosophy of one man one girl-at a time-would be helpful.

It should not be forgotten that, in the unlikely event of both syphilis and gonorrhoea being either eradicated altogether or merely 'tamed' to the point of representing no problems at all to the human race, many other conditions such as non-specific urethritis, trichomoniasis, candidiasis, genital herpes, venereal

TABLE XV Serum tests for gonorrhoea

\begin{tabular}{|c|c|c|c|c|c|}
\hline \multirow{2}{*}{ Method } & \multirow{2}{*}{ Authors } & \multirow{2}{*}{ Date } & \multicolumn{2}{|c|}{$\begin{array}{l}\text { Per cent. positivity in } \\
\text { gonorrhoea }\end{array}$} & \multirow{2}{*}{$\begin{array}{l}\text { Per cent. } \\
\text { positivity } \\
\text { in controls }\end{array}$} \\
\hline & & & Males & Females & \\
\hline $\begin{array}{l}\text { Flocculation } \\
\text { Protoplasm } \\
\text { Bentonite }\end{array}$ & $\begin{array}{l}\text { Lee and Schmale } \\
\text { Wallace, Diena, Yugi, and Greenberg }\end{array}$ & $\begin{array}{l}1970 \\
1970\end{array}$ & $\begin{array}{l}69 \\
77\end{array}$ & $\begin{array}{l}86 \\
78\end{array}$ & $\begin{array}{c}11-12 \\
4\end{array}$ \\
\hline Haemagglutination & $\begin{array}{l}\text { Logan, Cox, and Norins } \\
\text { Ward and Glynn }\end{array}$ & $\begin{array}{l}1970 \\
1971\end{array}$ & $\begin{array}{l}62 \\
46\end{array}$ & $\begin{array}{l}76 \\
84\end{array}$ & $\begin{array}{l}0-12 \\
0-4\end{array}$ \\
\hline Immunofluorescence & Under investigation & & & & \\
\hline
\end{tabular}


warts, molluscum contagiosum, scabies, and pubic lice (Table II) (not forgetting lymphogranuloma venereum, granuloma inguinale and soft sore plus some others yet to be found) will continue to be transmitted genitally and to represent considerable medical or social problems.

\section{Summary and conclusions}

(1) The increasing incidence of cases of the venereal diseases, particularly gonorrhoea, which is occurring in all continents is described. The many factors involved, including those concerned with changes in the environment, host, and organism, are outlined. Most of these adverse factors are likely further to aggravate the problem in the future.

(2) In such a situation drastic measures are required. The oft-expressed hope of a vaccine is still far from realization, but there are hopes in the near future of a screening test for gonorrhoea which may be applied to population groups without the need for a genital examination.

(3) Propaganda media should be employed to emphasize that if young persons frequently change their sexual partners venereal disease will inevitably result. Sufficient money should be provided to undertake this adequately.

(4) Even if gonorrhoea and syphilis could be eradicated from our society, there will always be many other sexually-transmitted diseases to create personal, marital, and social distress, so long as sexual intercourse is practised without restraint.

\section{References}

Abu-Nasser, H., Hill, N., Fred, H. L., and Yow, E. M. (1963) Arch. intern. med., 112, 731

AMER. SOC. Hlth Ass. (1968) 'Today's V.D. Control Problem', Joint Statement, pp. 28-33

(1970) Ibid., p. 56

Amies, C. R. (1969) Brit. F. vener. Dis., 45, 216

ARYA, G. P., and BenNett, F. J. (1967) Brit. f. vener. Dis., 43, 275

_- and Phillips, I. (1970) Brit. F. vener. Dis., 46, 149

BARR, J., and DANIELSSON, D. (1971) Brit. med. F., 1, 482

BeEse, D. H., ed. (1968) 'Tobacco Consumption in Various Countries'. Research Paper No. 6, 2nd ed. Tobacco Research Council, London

Brown, W. J. (1970) Brit. F. vener. Dis., 46, 118

- (1971) Paper presented at the International Venereal Disease Symposium, St. Louis, Mo, U.S.A.

Burton, J. (1968) Int. F. Hlth Educ., 11, 13

CAVE, V. G., Bloomfield, R. D., HuRdLe, E. S., Gordon, E. W., and Наммоск, D. (1969) f. Amer. med. Ass., 210, 309

Chacko, C. W., and NaIR, G. M. (1969) Brit. f. vener. Dis., 45, 33
Cobbold, R. J. C., Morrison, G. D., SPItzer, R. J., and Willcox, R. R. (1970) Postgrad. med. F., 46, 142

Cohen, L. (1970) Brit. F. vener. Dis., 46, 108

Collart, P., Borel, L.-J., and Durel, P. (1962) Ann. Inst. Pasteur, 102, 693

Cowan, L. (1969) Brit. F. vener. Dis., 45, 228

DALZELl-WARD, A. J. (1970) Brit. F. vener. Dis., 46, 159

Department of Health and Social Security (1969) 'On the State of the Public Health: Annual Report of Chief Medical Officer for 1968'. Appendix C, p. 257. H.M.S.O., London

Idem (1969) p. 236, H.M.S.O., London

Driscoll, A. M., MCCoy, D. R., Nicol, C. S., and BARrow, J. (1970) Brit. F. vener. Dis., 46, 125

Durel, P., RoIron, V., and Nicod, G. (1967) Path. et Biol., 15, 1197

ENFORS, W., and Molin, L. (1970) Brit. F. vener. Dis., 46, 209

Fischnaller, J. E., Pedersen, H. B., Ronald, R., Bonin, A. R., and TronCA, E. L. (1968) f. Amer. med. Ass., 203, 909

Fiumara, N. J., and BriLey, J. M. (1969) Brit. F. vener. Dis., 45, 254

- Wise, H. M., and MaNY, M. (1967) New Engl. F. Med., 276, 1248

FlukeR, J. L., and HewitT, A. B. (1970) Brit. f. vener. Dis., 46, 454

GaAl, R., Rich, R., and Hansman, D. (1968) Med. f. Aust., 1, 634

GALlAGHER, E. (1970) Brit. F. vener. Dis., 46, 129

GoldSCHNEIDER, I., GotsChlich, E. C., and ARTENSTEIN, M. S. (1969) F. exp. Med., 129, 1307

Gotschlich, E. C., Teh Yung LiU, and Artenstein, M. S. (1969) Ibid., 129, 1349

Gundersen, T., ÖdegaARd, K., and Gjessing, H. C. (1969) Brit. F. vener. Dis., 45, 235

Guthe, T. (1972) Postgrad. med. F., 43, Suppl. 1 (Jan.), p. 7 and IDsøE, O. (1964) T. Norsk. Laegeforen., 84, 1262

- (1968) Brit. F. vener. Dis., 44, 35

and WILlcox, R. R. (1971) Roy. Soc. Hlth F., 91, 122

Hatos, G. (1970) Med. F. Aust., 1, 1096

HewitT, A. B. (1970) Brit. f. vener. Dis., 46, 106

Holmes, K. K., Johnson, D. W., and Floyd, T. M. (1967) F. Amer. med. Ass., 202, 461

IDsøe, O., and GuTHE, T. (1967) Brit. F. vener. Dis., 43, 227

JENSEN, T. (1943) Ibid., 29, 222

Johnson, D. W., Holmes, K. K., Kvale, P. A., Halverson, C. W., and HirSCH, W. P. (1969) Amer. F. Epidemiol., 90, 438

JuHLIN, L., and LIDÉN, S. (1969) Brit. F. vener. Dis., 45, 321

_ and Wallin, J. (1972) Postgrad. med. F., 48, Suppl. 1 (Jan.), p. 12

Keys, T. F., Halverson, C. W., and Clarke, E. J. (1969) f. Amer. med. Ass., 210, 857

KING, A. (1970) Brit. med. F., 1, 451

KRAUS, G. W., and YeN, S. S. C. (1968) Obstet. and Gynec., 31, 258

Lee, L., and Schmale, J. D. (1970) Infect. and Immun., 1. 207 
Leigh, D. A., Le Franc, J., and Turnbull, A. R. (1969) Brit. F. vener. Dis., 45, 151

Logan, L. C., Cox, P. M., and Norins, L. C. (1970) WHO Document, WHO/VDT/RES GON.70.41

LomHolt, G., and BeRG, O. (1966) Brit. F. vener. Dis., 42, 1

LOUGHLIN, M. J. (1969) N.Z. med. F., 69, 195

LUGer, A. (1970) Paper given to 26th General Assembly, International Union against the Venereal Diseases and Treponematoses, Budapest. June 11-15, 1970

LyNN, R., Nicol, C. S., Ridley, M., Rimmer, D., Symonds, M. A. E., and WARREN, C. (1970) Brit. f. vener. Dis., 46, 404

Many, P., Reboul, E., Lapeyre, J., Boutet, R., Teillard J., Jeanpierre, G., and Saliba, G. (1967) Proph. sanit. morale, 39, 273

McKenzie-Pollock, J. S. (1970) Brit. F. vener. Dis., 46, 114

MCLone, D. G., Scotti, A. T., MaCKey, D. M., and HACKNEY, J. F. (1968) Ibid., 44, 220

Metzger, M., Michalska, E., Podwińska, J., and SMOGóR, W. (1969) Ibid., 45, 299

Miller, J. N., Bekrer, J. H., DeBruijn, J. H., and ONVLEE, P. C. (1969) F. Bact., 93, 132

Nicol, C. S., RIDLEY, M., and SyMONDS, M. A. E. (1968) Brit. F. vener. Dis., 44, 315

NielsEN, R. (1970) Ibid., 46, 153

OLSEN, G. A., and LOMHOLT, G. (1969) Ibid., 45, 144

Pariser, H., Farmer, A. D., and Marino, A. F. (1964) Sth. med. F., 57, 688

PlatTs, W. M. (1969) Brit. F. vener. Dis., 45, 61

Population Council (1969) February

Price, E. (1969) Medical Aspects of Human Sexuality, 3, 67

Reising, G., Schmale, J. D., Danielsson, D. G., and ThaYer, J. D. (1969) Appl. Microbiol., 18, 337

ReYN, A. (1969) Bull. Wld Hlth Org., 40, 257

Ronald, A. R., Eby, J., and SherRis, J. C. (1969) 'Antimicrobial Agents and Chemotherapy-1968', ed. G. L. Hobby, pp. 431-434

Rosenblatt, D., and Kabasakalian, L. (1966) Amer. $\mathcal{F}$. publ. Hlth, 56, 1104

SCHAMBERG, I. L. (1963) Brit. F. vener. Dis., 39, 87

Schmale, J. D., Martin, J. E., and Domescik, G. (1969) F. Amer. med. Ass., 210, 312

Smith, D. D., and Levey, J. M. (1967) Med. F. Aust., 1, 849

Smith, J. Lawton, and Israel, C. W. (1967) Arch. Ophthal. (Chicago), 77, 474

Thatcher, R. W., McCraney, W. T., Kellogg, D. S., and Whaley, W. H. (1969) f. Amer. med. Ass., 210, 315

Thayer, J. D., Samuels, S. B., Martin, J. E., and LUCAS, J. B. (1965) 'Antimicrobial Agents and Chemotherapy - 1964', p. 433. American Society for Microbiology, Ann Arbor, Mich.

Thin, R. N. T., and Michael, A. M. (1970) Brit. f. vener. Dis., 46, 126

UNITED NATIONS (1967) 'Demographic Year Book 1966'. New York

U.S. Center for Disease Control (1970) Morbidity and Mortality, 19, 74. United States Department of Health Education and Welfare, Atlanta, Georgia
Victoria, R. V., and ORdóÑez-Rosales, T. (1968) Rev. Invest. Salud. publ. (Mex.), 28, 119

Wallace, R., Diena, B. B., Yugi, H., and Greenberg, L. (1970) Canad. F. Microbiol., 16, 655

WARD, H. E., and GLYNN, A. A. (1971) Data presented at Zambon Foundation International Symposium on Gonorrhoea, Malaga, Spain, March, 1971

Waters, J. R., and Roulston, T. M. (1969) Amer. F. Obstet. Gynec., 103, 532

WEBSTER, B. (1966) Brit. f. vener. Dis., 42, 132

- (1970a) Ibid., 46, 406

(1970b) Ibid., 46, 156

WILLCoX, R. R. (1965) Ibid., 41, 287

- (1970a) Ibid., 46, 217

(1970b) Ibid., 46, 412

Wilson, D. C., and SutherLand, I. (1960) f. Obstet. Gynec., 67, 320

World Health ORganization (1963) WHO Expert Committee on Gonococcal Infections: First Report. WHO Tech. Rep. Ser., No. 262

- (1968) 'Report on Second Regional Seminar on Venereal Disease Control', Manila

- (1971) Press release WHO/8, 27 Jan., 1971

WREN, B. G. (1967) Med. f. Aust., 1, 847

Yobs, A. R., ClarK, J. W., Mothershed, S. E., Bullard, J. C., and ARTLEY, C. W. (1968) Brit. f. vener. Dis., 44, 116

ZWAHR, C. (1968) Zbl. Gynäk., 90, 1192

\section{Regard sur les maladies vénériennes à l'échelle mondiale}

\section{SOMMAIRE}

(1) On décrit l'incidence croissante des cas de maladies vénériennes, particulièrement de la gonococcie, telle qu'elle apparaît dans tous les continents. On souligne les multiples facteurs qui interviennent, dont ceux qui concernent les changements de l'environnement, de l'hôte et de l'organisme. La plupart de ces facteurs défavorables sont susceptibles d'aggraver le problème dans l'avenir.

(2) Dans une telle situation, des mesures énergiques sont requises. L'espoir souvent exprimé de posséder un vaccin reste loin de la phase de réalisation mais il y a des espoirs de disposer, dans un proche futur, d'un test de dépistage de la gonococcie qui pourrait être appliqué à des groupes de population sans nécessiter l'examen génital.

(3) Les moyens de propagande doivent être utilisés pour faire ressortir que, si les jeunes changent fréquemment leurs partenaires sexuels, ils s'exposent inévitablement aux maladies vénériennes. Un budget suffisant doit être obtenu pour entreprendre cette action d'une manière satisfaisante.

(4) Même si la gonococcie et la syphilis pouvaient être éliminées de notre société, aussi longtemps que les rapports sexuels seront pratiqués sans retenue, il restera bien d'autres maladies transmissibles sexuellement pouvant entraîner des détresses personnelles, conjugales et sociales. 